\title{
Prevalence of Non Organ-Specific Auto Antibodies and its Effect on Response to Antiviral Therapy in Patients with Chronic Hepatitis C Virus Genotype 4
}

\author{
Mohamed Abd El-Maksoud ${ }^{1}$, Hatem Elalfy ${ }^{1}$, Maha Ragab Habeeb ${ }^{2}$, \\ Abd-Elmohsen E. El-desoky ${ }^{2}$, Ziyad M. Tawhid ${ }^{3}$, Basem S. Eldeek ${ }^{4}$ \\ ${ }^{1}$ Tropical Medicine Unit, Mansoura University Hospital, Mansoura Faculty of \\ Medicine, Egypt \\ ${ }^{2}$ Internal Medicine, Mansoura University Hospital, Mansoura Faculty of Medicine \\ ${ }^{3}$ Clinical Immunology Unit, Clinical Pathology Department, Mansoura Faculty of \\ Medicine,Egypt \\ ${ }^{4}$ Public health and community Medicine King Abdulaziz University faculty of \\ medicine ,Jeddah, and Mansoura university, Egypt.
}

Corresponding Author Mohamed M. Abd ElMaksoud

Mobile:

$+201224873738$

E mail:

mohamedmaksoud201 0@hotmail.com

Key words: Hepatitis C virus, Autoantibodies, Antiviral therapy
Background and Study Aim: Immunological disorders have been frequently described in the course of hepatitis $\mathrm{C}$ virus (HCV)-related chronic hepatitis. Our aim was to determine the prevalence of non-organ-specific autoantibodies (NOSAs) and evaluate its impact on the response to combined antiviral therapy in patients with chronic HCV genotype-4.

Patients and Methods: A total of 134 adult patients with chronic HCV genotype-4 were investigated for the presence of serum Antinuclear antibody (ANA), antismooth muscle antibody (SMA), and anti liver/kidney microsomal antibody type 1 (LKM1). 109 out of $134 \mathrm{HCV}$ patients were treated naive and received combined antiviral therapy (pegylated interferonribavirin). The presence of these autoantibodies was studied in relation to the patient's characteristics and the outcome of antiviral therapy.

\section{INTRODUCTION}

Hepatitis $\mathrm{C}$ virus (HCV) is among the leading causes of chronic liver disease worldwide and affects approximately 170 million people [1]. Egypt has the highest prevalence of $\mathrm{HCV}$ infection of any country in the world, the situation is quite worse, the overall prevalence (percentage of people) positive for antibody to $\mathrm{HCV}$ was $14.7 \%$ [2]. Immunological disorders have been frequently described in the course of HCV-related chronic hepatitis, and non-organ-specific autoantibodies (NOSAs) in particular are common examples of
Results: Thirty-six (26.9\%) patients were positive for at least one autoantibody. Various autoantibodies were presented as follows: ANA in 29 (21.6\%) patients, SMA in $9(6.7 \%)$ and anti-LKM-1 in 2 $(1.5 \%)$. In two patients, both ANA and anti-SMA were positive, and in other two cases both ANA anti-LKM-1 were positive. Female patients had a higher prevalence of positive autoantibodies $(\mathrm{P}=0.005)$. Chronic hepatitis $\mathrm{C}(\mathrm{CHC})$ patients with positive autoantibodies had higher serum ALT, AST and GGT levels. The rate of sustained virological response to combined antiviral therapy was similar between autoantibody-positive and negative groups (46.9\% vs. $53.2 \%$ ).

Conclusion: Autoantibodies can be induced in the course of $\mathrm{CHC}$. Autoantibody-positive $\mathrm{CHC}$ patients are older and have higher disease activity and severity. However, the presence of these autoantibodies did not influence the response to combination antiviral therapy.

autoreactivity associated with $\mathrm{HCV}$ infection [3].

$\mathrm{HCV}$ has six major genotypes according to its viral genome, numbered one to six. These viral types and sub-types differ in their geographical distribution and antigenicity [4]. Particular genotypes are associated with different courses and outcome of liver diseases, and also with different responsiveness to interferon therapy. Results of the studies to clarify the relationship between HCV genotype and autoimmune manifestations are controversial. 
A majority of them failed to confirm the association between clinical course of $\mathrm{HCV}$ infection, autoimmune disorders and particular $\mathrm{HCV}$ genotypes. Genotype 4 is the predominant genotype of $\mathrm{HCV}$ in Egyptian patients (up to 91\%) [5].

To date, combination of pegylated interferon alpha (PEGIFN) and ribavirin is the treatment of choice for chronic HCV patients [6] with an (SVR) of $42 \%-52 \%$ in patients with genotype 1 $[7,8]$ and in $42-68 \%$ in those with genotype 4 (9-12). The achievement of the SVR in patients with chronic hepatitis $\mathrm{C}$ (CHC) has been associated with improvements in liver histology as well as a reduced risk of hepatocellular carcinoma (HCC) and liver-related mortality[1315]. However, several side-effects have been published in patients treated with IFN- $\alpha$ including the development or exacerbation of underlying autoimmune diseases and the development of a variety of organ and non-organ specific autoantibodies (NOSAs) .The association between these antibodies and either $\mathrm{HCV}$ per se or IFN-a related therapy is mainly based on epidemiological surveys [16-21] . Moreover, available data on the relationship between autoantibody seropositivity and the response to antiviral therapy in $\mathrm{CHC}$ patients are limited and controversial $[22,23]$.

In this study, we aimed to assess the prevalence of serum NOSAs in CHC patients. In addition, to evaluate its impact on the response to combined antiviral therapy (IFN or pegylated IFN plus ribavirin) in patients with $\mathrm{HCV}$ genotype 4related chronic hepatitis and to identify clinical, biochemical, or immunological features predictive of response to antiviral treatment.

\section{PATIENTS AND METHODS}

The study was conducted into two stages:

Stage I: a comparative cross sectional study among patients with chronic hepatitis $\mathrm{C}$ virus Genotype 4

Stage II: a case control study between patients with chronic hepatitis C virus Genotype 4 and healthy cross matched control

\section{Sample size and power of the study}

The sample size was calculated by Medcalc program available at www. Medcalc.be. At a level of $95 \%$ confidence with alpha error 0.05 . and the power of the study was settled at 80 and beta error .02 . The prevalence of auto-antibodies was supposed to be ranged from $20 \%$ to $10 \%$. The estimated sample is 86 patients. We try to increase the sample of patients to 134 patients to increase the power of the study. Limitation of our resources enforce us to have a control group of 60 subjects

A total of 134 consecutive $\mathrm{CHC}$ patients were admitted to this study during the period of July 2009 to January 2012 who visited clinics (inpatients and outpatients) of Mansoura University Hospital. They were 78 males and 56 females, with a mean age of $48.4 \pm 3.2$ years and 60 healthy controls with matched age and sex. All patients had positive HCV antibody with enzyme-linked immunosorbent assay (ELISA) (Murex anti-HCV (version 4.0) 7F51-06/-07, DiaSorin South Africa (Pty) Ltd, Republic of South Africa) and detectable HCV RNA (Appliedbiosystems, StepOne Real-time PCR system, USA) in the serum. Out of $134 \mathrm{HCV}$ patients, 109 were treated with combined antiviral therapy (peg IFN plus ribavirin), while the remaining patients were missed during the treatment period.

The exclusion criteria included human immunodeficiency virus coinfection, hepatitis B virus infection, autoimmune hepatitis (using the simplified criteria for the diagnosis of AIH) [24], patients who showed evidence of alcohol, illicit drug, or potentially hepatotoxic medication use and major contraindications to IFN or ribavirin therapy. Informed consent was obtained from all patients, and the research protocols were approved by the Medical Ethics Committee of Mansoura University Hospital.

\section{Detection of NOSA:}

Serum ANA was detected by ELISA (ORG 538, ORGENTEC Diagnostika GmbH, Germany), ASMA was detected by ELISA (QUANTA LiteTM Actin IgG ELISA 708785, INOVA Diagnostics, Inc.USA) and anti-LKM-1 was also detected by ELISA (QUANTA LiteTM LKM-1 ELISA 708745, INOVA Diagnostics, Inc.USA).

Among the laboratory parameters measured at baseline serum levels of alanineaminotransferase (ALT), aspartateaminotransferase (AST), total and direct bilirubin, albumin, alkaline phosphatase, $\gamma$ glutamyl transpeptidase (GGT) and $\alpha$-fetoprotein (AFP) were recorded and included in the analysis. Samples positive for HCV-RNA by real time PCR were subjected to genotyping of $\mathrm{HCV}$, 
by RT-PCR for the core domain using the primers modified by Ohno et al. (1997) [25] .

\section{Histological assessment:}

Liver biopsy was done for all patients before the initiation of therapy. The histological evaluation was assessed using the modified Knodell histology index and the Metavir scoring system reflecting the degree of hepatic inflammation and fibrosis [26,27]. Before treatment, informed consent was obtained from each patient.

\section{Treatment regimens and outcomes.}

A total of $32(88.9 \%)$ of 36 autoantibodies positive patients and $77(78.6 \%)$ of 98 autoantibodies negative patients had been treated with a combination therapy (either pegylatedIFN alfa-2a $180 \mu \mathrm{g}$ subcutaneously once a week or pegylated-IFN alfa-2b $1.5 \quad \mu \mathrm{g} / \mathrm{kg}$ subcutaneously once a week plus oral ribavirin 1000 or $1200 \mathrm{mg}$ /day for subjects weighing <75 or $\geq 75 \mathrm{~kg}$, respectively). According to $\mathrm{HCV}$ genotype, the predetermined duration of treatment was 48 weeks with a final efficacy evaluation at week 24 of follow-up.

Patients were regularly followed-up for physical examination, blood tests and virological assays. Treatment outcome was assessed as follows: sustained virological response (SVR) was defined as undetectable HCV RNA 24 weeks after treatment discontinuation; relapse was defined as HCV RNA clearance during treatment and reappearance during follow-up; and nonresponse was defined as a failure to clear HCV RNA at any time during treatment [28] .

\section{Statistical Analysis}

The data were collected and entered the computer. The data were statistical analyzed by using Statistical Package of Social Science (SPSS). The qualitative data were presented in the form of number and percentage. Chi-square with Yates correction was used as a test of significance for qualitative data when the expected cell less than 5. Chi-square test was used as test of significance for qualitative data when the expected cell more than 5. Significance was considered when $\mathrm{p}$ value less than 0.05 .

The quantitative data were presented in the form of mean and standard deviation. Student $t$ test was used as a test of significance for quantitative data of two groups. The fibrosis score was presented in the form of median and range. Mannwhitney $u$ test was used as a test of significance for fibrosis score. Significance was considered when $\mathrm{p}$ value less than 0.05 .

\section{RESULTS}

\section{Prevalence of NOSA in patients with chronic hepatitis $\mathbf{C}$ :}

Table (1) shows the prevalence of NOSAs in patients with chronic hepatitis $\mathrm{C}$ and control groups. Among total of 134 patients with chronic hepatitis C, thirty-six (26.9\%) were positive for at least one autoantibody. ANA was present in twenty-nine $(21.6 \%)$ patients, anti-SMA in nine (6.7\%) patients , and anti-LKM-1 was found in two $(1.5 \%)$ patients. In two of the patients, both ANA and anti-SMA were positive, and in other two cases both ANA anti-LKM-1 were positive. The prevalence of serum autoantibodies in patients with chronic hepatitis $\mathrm{C}$ was significantly higher than in healthy control $(\mathrm{p}<$ $0.05)$.

\section{Clinical significance of NOSAs in patients with chronic hepatitis $\mathbf{C}$ :}

Table (2) compares the clinical, laboratory and histological parameters between $\mathrm{CHC}$ patients with and without autoantibodies.

As regard demographic data, female patients had a higher frequency of positive autoantibodies $(P=0.005)$ and age was significantly higher in the autoantibody-positive $\mathrm{CHC}$ patients $(51.4 \pm 2.3)$ vs $(45.4 \pm 4.1)(\mathrm{P}<0.001)$.

The CHC patients with and without serum autoantibodies were analyzed with comprehensive clinical and biochemical examinations: autoantibodies-positive patients had significantly higher serum levels of ALT $(102 \pm 20.3) \quad$ vs $\quad(90 \pm 22.4) \quad(P=0.013), \quad$ AST $(96 \pm 15.13) \quad$ vs $\quad(72 \pm 16.7) \quad(P=0.023), \quad$ GGT $(76.3 \pm 15.2)$ vs $(50.9 \pm 12.7) \quad(\mathrm{P}<0.001)$ and AFP $(18 \pm 4.5)$ vs $(13 \pm 3.9)(P=0.012)$. Autoantibodiespositive patients had also higher fibrosis scores and significantly lower platelet counts (144 $\pm 30.2)$ vs $(186 \pm 25.12)(\mathrm{P}=0.004)$. No significant difference in HCV viral load between both groups.

\section{Response to combined antiviral therapy:}

Table (3) show the response of chronic HCVinfected patients to combined antiviral treatment (peg-IFN plus ribavirin). In autoantibodies positive patients, 15 (46.9\%) of $32 \mathrm{HCV}$-infected patients had a sustained virological response (SVR), whereas 9 patients $(28.1 \%)$ experienced 
nonresponse and 8 (25\%) experienced relapse. In their counterpart, autoantibodies negative $\mathrm{HCV}$ patients, the response rate was as follow: $53.2 \%$ SVR, $24.7 \%$ nonresponse and $22.1 \%$ relapse. The SVR rates were comparable between autoantiboies positive $v s$. autoantibodies negative patients (46.9\% vs $53.2 \%)$.

As regard the systemic autoimmune manifestations, one patient with positive serum autoantibodies developed hypothyrodism while in autoantibodies negative group, one patient developed diabetes mellitus, and another one developed hypothyroidism. These complications were controlled on therapy and did not required withdrawal of combination therapy.

\section{Predictors of response to antiviral therapy}

In this study, we compared patients with and without SVR (Table 4) in order to predict the factors associated with a favorable response to combined antiviral therapy. Among the clinical, biochemical, and histological parameters studied, our results showed that younger age $(\mathrm{P}<0.001)$, lower body mass index $(\mathrm{BMI})(\mathrm{P}<0.001)$, higher serum ALT $(\mathrm{P}<0.001)$, lower GGT $(\mathrm{P}<0.001)$, lower HCV viral load $(\mathrm{P}<0.001)$ levels and lower fibrosis score were significantly associated with SVR. In comparison serum ANA, ASMA and LKM-1 were not significantly different between patients with and without SVR.

Table (1) Prevalence of NOSAs in 134 patients with chronic hepatitis C and the control group:

\begin{tabular}{|l|c|c|c|c|c|}
\hline & $\begin{array}{c}\text { Case } \\
(\mathrm{n})\end{array}$ & $\begin{array}{c}\text { Autoantibodies } \\
(\mathrm{n}(\%))\end{array}$ & $\begin{array}{c}\text { ANA } \\
(\mathrm{n}(\%))\end{array}$ & $\begin{array}{c}\text { ASMA } \\
(\mathrm{n}(\%))\end{array}$ & $\begin{array}{c}\text { Anti-LKM-1 } \\
(\mathrm{n}(\%))\end{array}$ \\
\hline Patients with CHC & 134 & $36(26.9 \%)$ & $29(21.6 \%)$ & $9(6.7 \%)$ & $2(1.5 \%)$ \\
\hline Control group & 60 & $7(11.7 \%)$ & $7(11.7 \%)$ & $0(0 \%)$ & $0(0 \%)$ \\
\hline Test of significance & & $0.018^{*}$ & 0.098 & $.031 *$ & .47 \\
\hline
\end{tabular}

Table (2): Clinical, laboratory and histological parameters of patients with chronic hepatitis $\mathrm{C}$ who did or not test positive for non-organ specific autoantibodies.

\begin{tabular}{|c|c|c|c|}
\hline Parameters & $\begin{array}{c}\text { Autoantibody positive } \\
\mathrm{N}=36\end{array}$ & \begin{tabular}{|c|}
$\begin{array}{c}\text { Autoantibody negative } \\
\mathrm{N}=98\end{array}$ \\
\end{tabular} & $P$ value \\
\hline $\begin{aligned} \text { Gender } & \\
& \text { Male } \\
& \text { Female }\end{aligned}$ & $\begin{array}{l}14 \\
22\end{array}$ & $\begin{array}{l}64 \\
34\end{array}$ & $\mathrm{P}=0.005 * *$ \\
\hline Age (year) & $51.4 \pm 2.3$ & $45.4 \pm 4.1$ & $<0.001 * * *$ \\
\hline Body mass index & $26.1 \pm 2.1$ & $27.2 \pm 2.4$ & .059 \\
\hline Hb level (g/dl) & $13.6 \pm 1.2$ & $13.9 \pm 1.5$ & .28 \\
\hline WBCs & $5.9 \pm 2.1$ & $6.2 \pm 2.3$ & .19 \\
\hline Platlet count $\left(\times 10^{9} / \mathrm{I}\right)$ & $144 \pm 30.2$ & $186 \pm 25.12$ & $0.004 * *$ \\
\hline Albumin (g/dl) & $4.03 \pm 0.75$ & $4.2 \pm 0.32$ & .49 \\
\hline Total Bilirubin (mg/dl) & $1.04 \pm 0.5$ & $0.9 \pm .41$ & .101 \\
\hline ALT (IU/ml) & $102.3 \pm 20.3$ & $90.5 \pm 22.4$ & $0.013^{*}$ \\
\hline AST (IU/ml) & $96.4 \pm 15.13$ & $72.9 \pm 16.7$ & $0.023^{*}$ \\
\hline $\operatorname{ALP}(\mathrm{U} / \mathrm{I})$ & $247.08 \pm 42.3$ & $238.67 \pm 36.8$ & .37 \\
\hline GGT (IU/I) & $76.3 \pm 15.2$ & $50.9 \pm 12.7$ & $<0.001^{* * *} *$ \\
\hline $\begin{array}{l}\text { HCV RNA(×10 } \\
\text { IU/ml) }\end{array}$ & $0.58 \pm .2$ & $0.66 \pm .3$ & 0.141 \\
\hline AFP & $18.2 \pm 4.5$ & $13.3 \pm 3.9$ & $0.012^{*}$ \\
\hline Fibrosis score $(0-2 / 3,4)$ & $\begin{array}{l}21 / 15 \\
1(1-4)\end{array}$ & $\begin{array}{c}70 / 28 \\
2(1-4)\end{array}$ & $<0.001 * * *$ \\
\hline
\end{tabular}

* SIGNIFICAT P LESS THAN 0.05

\footnotetext{
** HIGHLY SIGNIFICANCE LESS THAN .01

**** EXTREMLY SIGNIFICANCE LESS LESS THAN .001
} 
Table (3): Response of chronic hepatitis $\mathrm{C}$ patients with and without autoantibodies to combined antiviral therapy

\begin{tabular}{|l|c|c|c|}
\hline & $\begin{array}{c}\text { Autoantibodies } \\
\text { positive patients } \\
\mathbf{N = 3 2}\end{array}$ & $\begin{array}{c}\text { Autoantibodies negative } \\
\text { patients } \\
\mathbf{N = 7 7}\end{array}$ & \multirow{2}{*}{ P value } \\
\cline { 1 - 3 } SVR & $15(46.9 \%)$ & $41(53.2 \%)$ & \multirow{2}{*}{$\mathbf{0 . 8 3}$} \\
\cline { 1 - 3 } Non responder & $9(28.1 \%)$ & $19(24.7 \%)$ & \\
\hline Relapse & $8(25 \%)$ & $17(22.1 \%)$ & \\
\hline
\end{tabular}

Table (4): Comparison between patients with SVR and Non-SVR

\begin{tabular}{|l|c|c|c|}
\hline & $\begin{array}{c}\text { SVR } \\
\mathbf{n = 5 6}\end{array}$ & $\begin{array}{c}\text { Non-SVR } \\
\mathbf{n = 5 3}\end{array}$ & P Value \\
\hline $\begin{array}{l}\text { Gender } \\
\text { Male/ Female }\end{array}$ & $31 / 25$ & $33 / 20$ & 0.46 \\
\hline Age (year) & $44 \pm 5.21$ & $52 \pm 4.2$ & $<0.001^{* * *}$ \\
\hline Body mass index & $25.3 \pm 2.31$ & $28.5 \pm 1.41$ & $<0.001^{* * *}$ \\
\hline ALT (IU/ml) & $116 \pm 25.7$ & $86 \pm 50.1$ & $<0.001^{* * *}$ \\
\hline AST (IU/ml) & $87.7 \pm 17.2$ & $82.5 \pm 19.2$ & 0.15 \\
\hline GGT (0-40IU/I) & $47.7 \pm 5.7$ & $82.3 \pm 6.2$ & $<0.001^{* * *}$ \\
\hline ANA (+/-) & $13 / 43$ & $16 / 37$ & .41 \\
\hline ASMA (+/-) & $4 / 52$ & $5 / 48$ & .51 \\
\hline Anti-LKM-1 & $1 / 55$ & $1 / 52$ & .96 \\
\hline HCV RNA $(\times \mathbf{1 0} \mathbf{6} \mathbf{I U} / \mathbf{m l )}$ & $0.49 \pm 0.56$ & $0.86 \pm 0.72$ & $<0.001^{* * *}$ \\
\hline Fibrosis score & 1 & 3 & $0.003^{* *}$ \\
\hline
\end{tabular}

\section{DISCUSSION}

Patients chronically infected by HCV present various immune-mediated phenomena mainly due to B lymphocyte dysfunction as mixed cryoglobulinemia and non-organ-specific autoantibodies (NOSAs) production [29]. Previous studies have shown that serum autoantibodies are commonly found in $\mathrm{CHC}$ patients [30]. In this study, the global prevalence of NOSAs among patients with chronic hepatitis $\mathrm{C}$ was $26.9 \%$. ANA was the most commonly found autoantibodies being present in $21.6 \%$ of patients. The prevalence of ANA is higher than that reported by studies from some countries [31], while it is comparable to that reported from some other countries. Lenzi et al., demonstrated the occurrence of ANA in 16\% of patients with chronic hepatitis C [21]. In Estonia, Zusinaite et al., reported $14.4 \%$ prevalence of ANA in patients with chronic hepatitis $C$ [32] . As regard the prevalence of ASMA in patients with chronic hepatitis $\mathrm{C}$, it was found to be $6.7 \%$. This result is lower than that reported in some studies $[16,21,32]$. Anti-LKM-1 autoantibodies are detected worldwide in approximately $0-7 \%$ of patients with chronic hepatitis C $[33,34]$. Available data on the prevalence of anti-LKM-1 in Egyptian patients with $\mathrm{CHC}$ are relatively uncommon. Here we reported that the positive rate of anti-LKM-1 was $1.5 \%$. These results confirm that AIH-related autoantibodies can exist in CHC patients.

Molecular mimicry between the $\mathrm{HCV}$ polyprotein and "self" proteins may account for the production of autoantibodies in chronic $\mathrm{HCV}$ infection. A sequence homology between the $\mathrm{HCV}$ polyprotein and cytochrome p450 2D6 (CYP 2D6), the antigenic target of anti-LKM1, was previously reported [35]. The reactivity against the viral protein would induce the production of anti-LKM1 in HCV-related CLD. Gregorio and colleagues documented molecular mimicry between HCV polyprotein and three nuclear host antigens including matrin, histone $\mathrm{H} 2$, and replication protein as a mechanism for the emergence of ANA [36]. Polyclonal B cell activation by persistent HCV infection has been proposed as another mechanism for the production of autoantibodies. In determining one 
of the mechanisms for polyclonal B cell activation, Pileri and colleagues documented that $\mathrm{HCV}$ envelope protein (E2) represented a costimulatory signal to $\mathrm{B}$ cells by binding to $\mathrm{CD} 81$ (tetraspanin) and thereby facilitated the production of autoantibodies [37] . Blymphocyte activating factor (BAFF) appeared to play a crucial role in HCV-induced autoimmunity [38].

Variations in the prevalence of autoantibodies may be attributed to several factors. First, there may be differences in viral strains causing these differences [3]. Secondly, the differences in detection methods, ethnic background and geographic distribution of the study cohort [39] .

In our study, patients with positive autoantibodies were significantly older. This is in agreement with the findings of Squadrito et al., [16], who found that NOSAs positive HCV patients were older than those with negative autoantibodies. This phenomenon might result from functional defects in suppressor $\mathrm{T}$ cells in older patients [40,41]. However, other studies found no age difference between the two groups $[42,43]$. The positive rate of autoantibodies was higher in females, which is in accord with reports by other groups $[31,44]$. This may reflect the difference in autoimmune reactions between males and females after CHC infection, suggesting that hormones, such as estrogen, may play an important role in infection [45] .

As regard the biochemical finding, this study showed that autoantibody-positive CHC patients had significantly higher serum ALT and AST levels than those without autoantibodies. This is in agreement with previous reports by Lenzi, et al., who reported that NOSAs were significantly prevalent in patients with HCV-related chronic liver disease, and were especially so when the alanine aminotransferase activity was higher [21]. Moreover, Cassani, et al., showed in a prospective series of patients with HCV related chronic liver disease who were positive for autoantibodies, a biochemical and histological activity were higher than that of patients with no markers of autoimmunity [46]. In controversy, Stroffolini et al., showed no correlation between the positivity of autoantibodies and liver damage [43]. Muratori, et al., showed that in the absence of active liver disease the prevalence of nonorgan specific autoantibodies was similar in HCV positive individuals and negative controls [3]. This suggests that the presence of non-organ- specific autoantibodies is more likely associated with increased patient's age, duration and severity of chronic liver disease. Thus, reactivity against self-antigens can be related to the severity of liver damage without any independent pathogenic role.

Our finding also demonstrated that NOSApositive CHC patients had low platelet count and more advanced fibrosis scores than seronegative $\mathrm{CHC}$ patients. These finding are in agreement with most published data, suggesting that HCVinfected autoantibody- positive patients have higher disease activity and severity than those who are autoantibody-negative $[46,47]$.

IFN-alfa is the treatment of choice for patients with chronic hepatitis $\mathrm{C}$, but its immunomodulatory activity may also favor the appearance or amplification of autoimmune reactions [48]. The response to IFN- $\alpha$ in patients with $\mathrm{HCV}$ infection and autoimmune markers continue to be controversial [42]. In our study, we found that the presence of serum NOSA in CHC patients did not influence the response to combined antiviral therapy, which was similar in both serum NOSA-positive and -negative patients (46.9 \% vs 53.2\%). This results is in agreement with other studies who reported that the presence of autoantibodies such as ANA or anti-LKM1 in patients with CHC is less likely to affect the response to antiviral treatment $[46,49]$. In contrast, the favourable pridectors of SVR were younger age, lower body mass index (BMI), higher serum ALT, lower GGT, lower HCV viral load levels and lower fibrosis score. These results are in agreement with other reports as in all large prospective studies of (PEG) IFN and RBV combination therapy younger age correlated significantly with an SVR when assessed by univariate and multivariate analyses and patients younger than 40-45 years showed the best response rates [50]. GGT has been identified as a prognostic factor in other studies $[51,52]$. In this study, we found that low GGT level had a favorable prediction of SVR. This is in accordance with previous reports in which low pre-treatment serum GGT levels were significantly and independently associated with SVR in multivariate regression analysis $[53,54]$. The pathogenetic background of GGT elevation in chronic hepatitis $\mathrm{C}$ is not fully understood. However a close relationship between serum GGT levels and hepatic steatosis, advanced fibrosis, and insulin resistance has been described [55,56]. Moreover, GGT levels are 
related with an increased expression of $\mathrm{TNF} \alpha$ in the liver that seems to reduce the efficacy of antiviral therapy [57] . We also confirmed previous reports signaling that a low viral load is predictor of SVR. A low baseline viral load ( $<600,000-800,000 \mathrm{IU} / \mathrm{ml}$ or less) was shown to be an independent predictor of SVR regardless of genotype in numerous studies $[50,53,58,59]$.

In conclusion, serum NOSA $A_{S}$ were frequently found in $\mathrm{HCV}$-infected patients. Patients with positive serum autoantibodies were older, and have higher disease activity and advanced fibrosis scores than their negative counterparts. The positivity of autoantibodies did not influence the response to combination antiviral therapy. Combined antiviral treatment is safe and effective in autoantibodies-positive patients with CHC. Routine testing of autoantiantibodies may be needed to monitors the progress and severity of disease that might be areas for further research.

\section{Limitation of the study:}

Some limitations should be considered when interpreting our findings. First, detection of autoantibodies was based on ELIZA method, and there was no record of the distribution type of NOSAs. Whether the distribution type of autoantibodies has clinical relevance is worthy of future study. Second, the external validity of this study is questionable, since the sample of the patients may not be representative of all Egyptian population due to cost variable, long duration of follow up and the interferon therapy is not available for most of Egyptian patients; therefore, it is possible that our findings cannot be extrapolated to all CHC patients in Egypt.

Funding: No funding resourses .

Conflicts of interest: The authors report no conflicts of interest. The authors alone are responsible for the content and writing of the paper.

\section{Ethical approval: Approved.}

\section{REFERENCES}

1. Lavanchy D. The global burden of hepatitis C. Liver Int 2009; 29: 74-81.

2. El-Zanaty, Fatma and Ann Way. Egypt Demographic and Health Survey 2008. Cairo, Egypt: Ministry of Health, El-Zanaty and Associates, and MacroInternational. 2009.

3. Muratori P, Muratori L, Stroffolini T, Pappas G, Terlizzi P, Ferrari R, et al. Prevalence of non organ specific autoantibodies in $\mathrm{HCV}$-infected subjects in the general population. Clin Exp Immunol 2003; 131:118-21.

4. .Sy T, Jamal MM. Epidemiology of hepatitis C virus (HCV) infection. Int J Med Sci 2006;3 (2):41-6.

5. Ray SC, Arthur RR, Carella A, Bukh J, Thomas D. Genetic epidemiology of hepatitis C virus throughout Egypt. J Infect Dis. 2000;182:698707.

6. Strader DB, Wright T, Thomas DL, Seeff LB . Diagnosis, management, and treatment of hepatitis C. Hepatology2004; 39: 1147-71.

7. Manns MP, McHutchison JG, Gordon SC, Rustgi VK, Shiffman M, Reindollar R, et al. Peginterferon alfa-2b plus ribavirin compared with interferon alfa- $2 b$ plus ribavirin for initial treatment of chronic hepatitis $\mathrm{C}$ : a randomised trial. Lancet 2001;358:958-965.

8. Fried MW, Shiffman ML, Reddy KR, Smith C, Marinos G, Gonçales FL Jr, et al. Peginterferon alfa-2a plus ribavirin for chronic hepatitis $\mathrm{C}$ virus infection. N Engl J Med 2002;347:975-982.

9. Esmat G, Abouzied A, Abdel-Aziz F . Treatment with PEG-IFN alfa-2b plus ribavirin compared to interferon alfa-2b plus ribavirin in subjects with chronic hepatitis Cinfected with HCV genotype 4 .Hepatology 2002;36: 364A.

10. Alfaleh FZ, Hadad Q, Khuroo MS . Peginterferon alpha-2b plus 40. ribavirin compared with interferon alpha-2b plus ribavirin for initial treatment of chronic hepatitis C in Saudi patients commonly infected with genotype 4. Liver Int .2004; 24(6): 568-574.

11. Derbala M, Amer A, Bener A . Pegylated interferon-alpha 2b-ribavirin combination in Egyptian patients with genotype 4 chronic hepatitis. J Viral Hepat.2005; 12(4): 380-385.

12. El-Zayadi A, Attia M, Barakat E . Response of hepatitis $C$ genotype-4 naïve patients to 24 weeks of Peg-interferon-alpha2b/ribavirin or inductiondose interferon alpha2b/ribavirin/amantadine: a non-randomized controlled study. Am $J$ Gastroenterol.2005; 100(11): 2447-2452.

13. Berenguer J, Alvarez-Pellicer J, Martín PM, López-Aldeguer J, Von-Wichmann MA, Quereda $\mathrm{C}$, et al. Sustained virological response to interferon plus ribavirin reduces liver-related complications and mortality in patients coinfected with human immunodeficiency virus and hepatitis C virus. Hepatology 2009;50:407-413.

14. George SL, Bacon BR, Brunt EM, Mihindukulasuriya KL, Hoffmann J, Di Bisceglie AM. Clinical, virologic, histologic, and biochemical outcomes after successful HCV therapy: a 5-year follow-up of 150 patients. Hepatology 2009;49:729-738.

15. Hung $\mathrm{CH}$, Lee CM, Lu SN, Wang JH, Hu TH, Tung HD, et al. Long-term effect of interferon alpha-2b plus ribavirin therapy on incidence of hepatocellular carcinoma in patients with 
hepatitis C virus-related cirrhosis. J Viral Hepat 2006; 13:409-414.

16. Squadrito G, Previti M, Lenzi M, Le Rose EP, Caccamo G, Restuccia T, et al. High prevalence of non- organ-specific autoantibodies in hepatitis $\mathrm{C}$ virus-infected cirrhotic patients from southern Italy. Dig. Dis. Sci.2003; 48: 349-353.

17. Wu YY, Hsu TC, Chen TY, Liu TC, Liu GY, Lee YJ, et al. Proteinase 3 and dihydrolipoamide dehydrogenase (E3) are major autoantigens in hepatitis C virus (HCV) infection. Clin Exp Immunol 2002; 128: 347-52.

18. Monti V, Aghemo A, Rumi MG, Donato MF, Del Ninno E, Colombo M. The prevalence, clinical features and response to antiviral therapy of patients with chronic hepatitis $\mathrm{C}$ who are seropositive for liver-kidney microsome type 1 antibodies. Antivir Ther 2005; 10(6): 715-20.

19. Dalekos GN, Kistis KG, Boumba DS, Voulgari P, Zervou EK, Drosos AA, et al. Increased incidence of anti-cardiolipin antibodies in patients with hepatitis $\mathrm{C}$ is not associated with aetiopathogenetic link to anti-phospholipid syndrome. Eur J Gastroenterol Hepatol 2000; 12(1): 67-74.

20. Fattovich G, Giustina G, Favarato S, Ruol A. A survey of adverse events in 11,241 patients with chronic viral hepatitis treated with alfa interferon. J Hepatol 1996; 24: 38-47.

21. Lenzi M, Bellentani S, Saccoccio G, Muratori P, Masutti F, Muratori L, et al. Prevalence of nonorgan-specific autoantibodies and chronic liver disease in general population: a nested casecontrol study of the Dionysos cohort. Gut 1999; 45: 435-441

22. Wasmuth HE, Stolte C, Geier A, Dietrich CG, Gartung C, Lorenzen J, et al. The presence of nonorgan- specific autoantibodies is associated with a negative response to combination therapy with interferon and ribavirin for chronic hepatitis C. BMC Infect Dis 2004;4:4.

23. Muratori P, Muratori L, Guidi M, Granito A, Susca M, Lenzi M, et al. Clinical impact of nonorgan-specific autoantibodies on the response to combined antiviral treatment in patients with hepatitis C. Clin Infect Dis 2005;40:501-7.

24. Hennes EM, Zeniya M, Czaja AJ, Parés A, Dalekos GN, Krawitt EL. et al. Simplified criteria for the diagnosis of autoimmune hepatitis. Hepatology. 2008;48:169-176.

25. Ohno O, Mizokami M, Wu RR, Saleh MG, Ohba $\mathrm{K}$, Orito $\mathrm{E}$, et al. New hepatitis $\mathrm{C}$ virus (HCV) genotyping system that allows for identification of HCV genotypes 1a, 1b, 2a, 2b, 3a, 3b, 4, 5a, and 6a. J Clin Microbiol. 1997 Jan;35(1):201-7.

26. Bedossa P, Poynard $T$ and French METAVIR Cooperative Study Group. An algorithm for grading activity in chronic hepatitis C. Hepatol 1996; 24: 289-93.
27. Ishak K, Baptista A, Bianchi L, Callea F, Groote JD, Gudat F, et al. Histological grading and staging of chronic hepatitis. J Hepatol 1995; 22: 696-699.

28. Feld JJ, Hoofnagle JH. Mechanism of action of interferon and ribavirin in treatment of hepatitis C. Nature 2005; 436:967-72.

29. Dustin LB, and Rice CM. Flying under the radar: the immunobiology of hepatitis C. Аnnu Rev Immunol. 2007; 25:71-99.

30. Boyer N, Marcellin P. Pathogenesis, diagnosis and management of hepatitis C. J Hepatol 2000;32 Suppl 1:98 112.

31. Yee LJ, Kelleher P, Goldin RD, Marshall S, Thomas HC, Alberti A, et al. Antinuclear antibodies (ANA) in chronic hepatitis $\mathrm{C}$ virus infection: correlates of positivity and clinical relevance. J Viral Hepat 2004; 11: 459-464.

32. Zusinaite E, Metsküla K, Salupere R. Autoantibodies and hepatitis $\mathrm{C}$ virus genotypes in chronic hepatitis C patients in Estonia World $\mathrm{J}$ Gastroenterol 2005;11(4):488-491

33. Czaja AJ, Carpenter HA, Santrach PJ, Moore SB, Taswell HF and Homburger HA (1993): Evidence against hepatitis viruses as important causes of severe autoimmune hepatitis in the United States. J Hepatol; 18: 342-352.

34. Nishioka M, Morshed SA, Kono K, Himoto T, Parveen S, Arima K, et al. (1997): Frequency and signifcance of antibodies to P450IID6 protein in Japanese patients with chronic hepatitis C. $J$. Hepatol.; 26(5):992-1000.

35. Bogdanos DP, Choudhuri K, Vergani D. Molecular mimicry and autoimmune liver disease: virtuous intentions, malign consequences. Liver. 2001;21(4):225-32.

36. Gregorio GV, Choudhuri K, Ma Y, Pensati P, Iorio $\mathrm{R}$, Grant $\mathrm{P}$, et al. Mimicry between the hepatitis $\mathrm{C}$ virus polyprotein and antigenic targets of nuclear and smooth muscle antibodies in chronic hepatitis $\mathrm{C}$ virus infection. Clin Exp Immunol. 2003;133(3):404-13.

37. Pileri P, Uematsu Y, Campagnoli S, Galli G, Falugi F, Petracca R, et al. Binding of hepatitis $\mathrm{C}$ virus to CD81. Science. 1998;282(5390):93841.

38. Sene D, Limal N, Ghillani-Dalbin P, Saadoun D, Piette JC, Cacoub P. Hepatitis C virus-associated B-cell proliferation- -the role of serum B lymphocyte stimulator (BLyS/BAFF). Rheumatology (Oxford). 2007;46(1):65-9.

39. Pawlotsky JM, Roudot-Thoraval F, Simmonds P, Mellor J, Ben Yahia MB, Andre C, et al. Extrahepatic immunologic manifestations in chronic hepatitis $\mathrm{C}$ and hepatitis $\mathrm{C}$ virus serotypes. Ann Intern Med 1995; 122: 169-173.

40. Tomer Y, Shoenfeld Y. Ageing and autoantibodies. Autoimmunity 1988;1:141-9. 
41. Antel JP, Oger JJ, Dropcho E, Richman DP, Kuo HH, Arnason BG. Reduced T-lymphocyte cell reactivity as a function of human aging. Cell Immunol 1980;54:184-92.

42. Clifford BD, Donahue DG, Smith L, Cable E, Luttig B, Manns M et al. High prevalence of serologic markers of auto-immunity in patients with chronic hepatitis C. Hepatology 1995; 21: 613-619.

43. Stroffolini T, Colloredo G, Gaeta GB, Sonzogni A, Angeletti S, Marignani M, et al. Does an 'autoimmune' profile affect the clinical profile of chronic hepatitis C? An Italian multicentre survey. J. Viral. Hepat.2004; 11: 257-262.

44. Hsieh MY, Dai CY, Lee LP, Huang JF, Tsai WC, Hou NJ, et al. Antinuclear antibody is associated with a more advanced fibrosis and lower RNA levels of hepatitis $\mathrm{C}$ virus in patients with chronic hepatitis C. J Clin Pathol 2008; 61: 333-337.

45. Whitacre CC. Sex differences in autoimmune disease. Nat Immunol 2001; 2: 777-780.

46. Cassani F, Cataleta M, Valentini P, Muratori P, Giostra F, Francesconi R, et al. Serum autoantibodies in chronic hepatitis $\mathrm{C}$ : comparison with autoimmune hepatitis and impact on the disease profile. Hepatology 1997;26:561-6.

47. Noda K, Enomoto N, Arai K, Masuda E, Yamada Y, Suzuki K, et al. Induction of antinuclear antibody after interferon therapy in patients with type-C chronic hepatitis: its relation to the efficacy of therapy. Scand $J$ Gastroenterol 1996;31:716-22.

48. Garcia-Buey L, Garcia-Monzon C, Rodriguez S, Borque MJ, Garcia-Sanchez A, Iglesias R, et al. Latent auto-immune hepatitis triggered during interferon therapy in patients with chronic hepatitis C. Gastroenterology 1995; 108(6): 1770-1777.

49. Iijima $\mathrm{Y}$, Kato $\mathrm{T}$, Miyakawa $\mathrm{H}$, Ogino $\mathrm{M}$, Mizuno M, Sugihara K, et al. Effect of interferon therapy on Japanese chronic hepatitis $\mathrm{C}$ virus patients with anti-liver/kidney microsome autoantibody type 1. J Gastroenterol Hepatol. 2001;16(7):782-8.

50. Shiffman ML, Suter F, Bacon BR, Nelson D, Harley H, Sola R, et al. Peginterferon alfa-2a and ribavirin for 16 or 24 weeks in HCV genotype 2 or 3. N Engl J Med 2007;357:124-134.

51. Mihm U, Herrmann E, Sarrazin C, Zeuzem S. Peredicting response in hepatitis $\mathrm{C}$ virus therapy. Aliment Pharmacol Ther 2006; 23: 1043-54.
52. Hernandez A, Domper F, Leon A, Lorente R, Lopez B, de la Santa E, et al. Viral kinetics during the first month of treatment in patients with genotype 1 chronic hepatitis C. Rev Esp Enferm Dig 2009; 101: 671-9.

53. Berg $T$, von Wagner M, Nasser S, Sarrazin C, Heintges T, Gerlach T, et al. Extended treatment duration for hepatitis $C$ virus type 1: comparing 48 versus 72 weeks of peginterferon-alfa- 2a plus ribavirin. Gastroenterology 2006;130:10861097.

54. von Wagner M, Huber M, Berg T, Hinrichsen H, Rasenack J, Heintges $\mathrm{T}$, et al. Peginterferonalpha-2a (40KD) and ribavirin for 16 or 24 weeks in patients with genotype 2 or 3 chronic hepatitis C. Gastroenterology 2005; 129:522-527.

55. Hwang SJ, Luo JC, Chu CW, Lai CR, Lu CL, Tsay $\mathrm{SH}$, et al. Hepatic steatosis in chronic hepatitis $\mathrm{C}$ virus infection: prevalence and clinical correlation. J Gastroenterol Hepatol 2001;16:190-195.

56. Silva IS, Ferraz ML, Perez RM, Lanzoni VP, Figueiredo VM, Silva AE. Role of gammaglutamyl transferase activity in patients with chronic hepatitis C virus infection. $J$ Gastroenterol Hepatol 2004;19:314-318.

57. Taliani G, Badolato MC, Nigro G, Biasin M, Boddi V, Pasquazzi C, et al. Serum concentration of $\gamma \mathrm{GT}$ is a surrogate marker of hepatic TNF- $\alpha$ mRNA expression in chronic hepatitis C. Clin Immunol 2002; 105: 279-85.

58. Jacobson IM, Brown Jr RS, Freilich B, Afdhal N, Kwo PY, Santoro J, et al. Peginterferon alfa-2b and weight-based or flatdose ribavirin in chronic hepatitis C patients: a randomized trial. Hepatology 2007;46:971-981.

59. Zeuzem S, Buti M, Ferenci P, Sperl J, HorsmansY, Cianciara J, et al. Efficacy of 24 weeks treatment with peginterferon alfa- $2 b$ plus ribavirin in patientswithchronic hepatitisCinfectedwith genotype 1 and low pretreatment viremia. J Hepatol 2006;44:97-103.

Peer reviewer: Abeer Nafee; Professor of Tropical Medicine, Faculty of Medicine, Zagazig Universiry, Egypt, Consultant Gastroenterologist and Hepatologist .

Editor : Tarik Zaher; Assistant Professor of Tropical Medicine, Faculty of Medicine, Zagazig Universiryb, Egypt, Consultant Gastroenterologist and Hepatologist 